\title{
フォスファゼン塩基を用いる芳香環化合物の新規脱プロトン一修飾反応
}

\author{
今 堀龍志
}

\section{A Novel Deprotonative Functionalization of Aromatics with Phosphazene Base}

\author{
Tatsushi IMAHORI \\ Graduate School of Pharmaceutical Sciences, Tohoku University, Aobayama, Aoba-ku, Sendai 980-8578, Japan
}

(Received April 5, 2004)

\begin{abstract}
A novel type of deprotonative functionalization of aromatics was accomplished with a phosphazene base $(t-\mathrm{Bu}-\mathrm{P} 4$ base). For various nitrogen heteroaromatics and benzene derivatives, deprotonative 1,2-additions proceeded with the $t$ $\mathrm{Bu}-\mathrm{P} 4$ base and $\mathrm{ZnI}_{2}$ as an additive in the presence of carbonyl compounds. The $t$-Bu-P4 base has both extremely strong Brønsted basicity and less nucleophilicity due to its huge, widely conjugated structure, and highly chemoselective deprotonations were achieved. In addition the nonmetallic $t$-Bu-P4 base should not function as a Lewis acid. Therefore the deprotonation with the $t$-Bu-P4 base is considered to proceed via a different pathway from traditional deprotonative metalation of aromatics with metallic bases. Some reactions with unique regioselectivities were observed.
\end{abstract}

Key words — aromatics; deprotonative functionalization; phosphazene base

\section{1. はじめに}

有機化合物の効率的変換反応は，環境調和を志向 した現代の有機化学のあるべき姿であり，近年， “Atom Economy”1)を唱えた高効率的有機合成反 応の開発が進められている. C-H 結合を直接的に 修飾する変換反応は，前駆物質の調製の必要がな く, 効率的変換反応の 1 つと捕らえることができ る。われわれは， $\mathrm{C}-\mathrm{H}$ 結合を直接修飾する脱プロ トン一修飾反応に着目し, 中でも芳香環化合物の選 択的修飾反応の開発を試みてきた. ${ }^{2-6)}$ 芳香環化合 物の脱プロトン一修飾反応は，芳香環プロトンの酸 性度が低いことから，通常，強力なブレンステッド 塩基性を有する有機リチウム塩基などの金属性塩基 が必要である。このような強力な金属性塩基は塩基 自体が高い求核活性を有する場合が多く，親電子性 の基質の反応への適用は一般に困難である。また生 成する芳香族金属化合物も高い求核活性を有するた め，親電子性の基質においては自己縮合反応が進行 してしまう場合がある。金属性塩基による芳香族脱

東北大学大学院薬学研究科（干980-8578 仙台市青葉区 荒巻字青葉)

e-mail: imahoritandon@yahoo.co.jp

本総説は, 平成 15 年度日本薬学会東北支部若手研究者

奨励賞の受賞を記念して記述したものである.
プロトン一修飾反応は, 親電子性基質に対して化学 選択性の低い反応である。われわれはこのような化 学選択性の問題点を克服すべく, 穏やかな反応活性 を有する脱プロトン化としてアミノ亜鉛アート錯体 を設計し，高化学選択的な反応を開発してい る. ${ }^{2-4)}$ また, 同様に穏やかな反応性を有する塩基 としてマグネシウムアミドを用いる反応も開発され ている. ${ }^{5-7)}$ 芳香族脱プロトン一修飾反応の制御に おいて, 化学選択性とともに反応の位置選択性も重 要な要素である。金属性塩基を用いる通常の芳香族 脱プロトン一修飾反応は, 一般に, 配位性へテロ原 子を含む置換基のオルト位, あるいはへテロ環へテ 口原子の $\alpha$ 位選択に進行し, 位置選択的な芳香環 修飾を行うことができる。このような位置選択性 は，塩基の金属の Lewis 酸性による基質一塩基間の キレーションの効果により決定されると理解されて いる. ${ }^{8-17)}$ しかしながら, 配位環境を複数伴う基質 に対しては, 選択する反応条件により位置選択性に 変動が見られ，それらを精密に制御した例は少な い. 18-21) 従来までの金属性塩基による芳香族脱プ ロトン一修飾反応は, 金属反応種の反応活性が化学 選択性を決定し，また金属性塩基のキレーションの 効果により位置選択性が決定されると理解すること ができ，金属が反応の選択性を制御する有機金属の 
化学として捕らえることができる. 今回, 従来まで はほとんど開発されていなかった非金属性，非イオ ン性有機塩基による芳香環化合物の脱プロトン一修 飾反応の開発を試みた。本稿では非金属性，非イオ ン性有機塩基である $t$-Bu-P4 塩基による，新しい選 択性を有する新規芳香環修飾反応について概説する.

\section{2. 塩基の選択}

芳香環プロトンの酸性度の低さから, 芳香族脱プ ロトン一修飾反応を実現し得る塩基は, 強いブレン ステッド塩基性を有する必要がある. 通常の芳香族 脱プロトン一修飾反応に用いられる金属性塩基は芳 香環プロトンを引き抜く強力な塩基性を有す

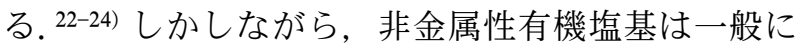
金属性塩基に比べ低いブレンステッド塩基性を示す （有機塩基の中では強力な DBU も金属性塩基に比 べて塩基性はかなり低い）（Fig. 1)。25）一般的な非 金属性有機塩基による芳香族脱プロトン一修飾反応 は，これまで報告がない。これに対し近年，興味深 い非金属性，非イオン性の有機塩基が開発され，有 機化学に利用されるようになってきている。 フォス ファゼン塩基 ${ }^{26,27)}$ は複数のフォスファゼンユニット が組み合わさった構造を有し（Fig. 2)，共役酸の
カチオン性を広範囲に非局在化し, 共鳴構造を安定 化することにより著しく強力なブレンステッド塩基 性を示すと考えられている. ${ }^{27)}$ フォスファゼンユニ ットの増加（ユニット数 1-4）とともにブレンス テッド塩基性は増強され，フォスファゼンユニット を 4 つ有する P4 塩基は金属性塩基に匹敵する塩基 性を示す (Fig. 2). 26,27) フォスファゼン塩基の表記 は，一般に Pn 塩基の形で示され， $n$ にフォスファ ゼンユニット数を示す.フォスファゼン塩基の中で も強力な塩基性を示す P4 塩基を用いることにより 芳香族脱プロトン一修飾反応が実現可能であると考 えた.

実際に， $t$-Bu-P4 塩基を用いた芳香族脱プロトン 一修飾反応は，限られた例ではあるが可能性が示さ れている (Scheme 1). ${ }^{26-29)}$ わわわは， $t$-Bu-P4 塩基による芳香族脱プロトン一修飾反応の開発を試 みることとした。

また， $t$-Bu-P4 塩基は強力なブレンステッド塩基 性とともに低い求核性を有することが知られてい る. ${ }^{27)}$ 求核性の低い塩基を用いることで，親電子性 の基質に対する化学選択的な脱プロトン一修飾反応 及び親電子剂共存下での反応が可能であると考えら れ，これにより一反応段階の効率的変換反応が可能

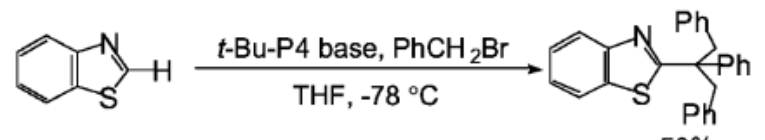

Detailed conditions are not described.

ca. $50 \%$

Scheme 1.

Fig. 1.
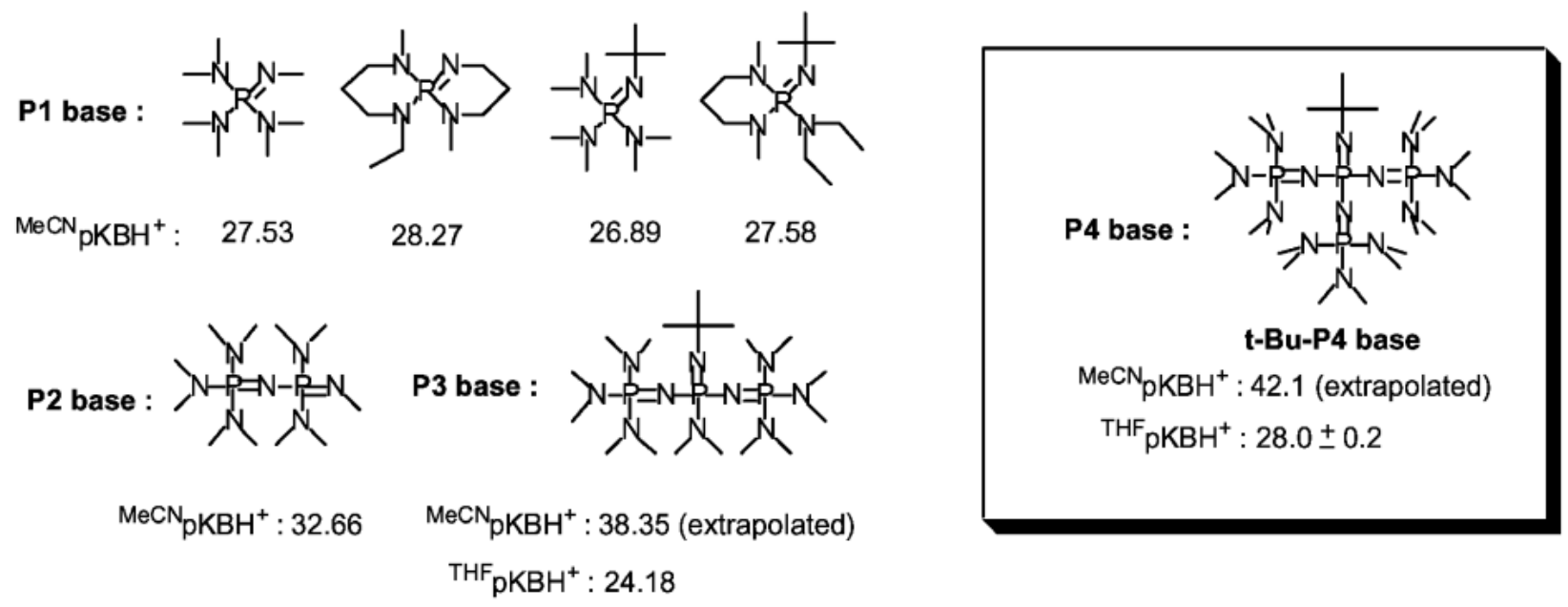

Fig. 2. 
となると考えた. ${ }^{30-36)}$

$t$-Bu-P4 塩基による芳香族脱プロトン一修飾反応 の可能性が示されているベンゾチアゾールに対し， 親電子剂共存下，一反応段階の芳香族脱プロトン一 修飾反応の検討を行った。親電子剂として種々カル ボニル化合物を用いたところ，ベンゾイルクロライ ド，ベンズアルデヒド，ベンゾフェノンに対し，脱 プロトンー1,2 付加反応が進行したと考えられる生 成物を与えた。 ベンズアルデヒドを用いた場合には， 1,2- 付加反応後にアルコール体が酸化されて生成し たものと考えられるベンゾイル体が得られた。また ベンゾイルクロライドとの反応では，ベンゾチア ゾール環がアニオンの生成とともに開環し，S-ベ ンゾイル化されたイソニトリル誘導体が得られた。 これらの反応では目的物は得られていないが，いず れもベンゾチアゾールの 2 位のアニオンの生成を経 て反応が進行しているものと考えられる。興味深い ことに, 安息香酸エチルエステル, シクロへキセノ ンに対しては，この条件下，反応は進行しなかった (Table 1).

$t-\mathrm{Bu}-\mathrm{P} 4$ 塩基を用い，適切な親電子剤を適用する ことにより, ベンゾチアゾールの脱プロトンー 1,2 付加反応が一反応段階で進行した。

Table 1. Deprotonative 1,2-Addition of Benzothiazole with $t$ Bu-P4 Base

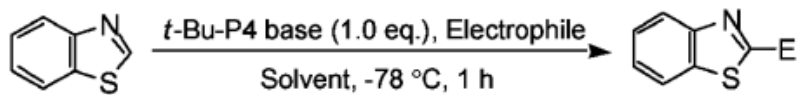

Run Solvent Electrophile

\section{3. 反応の適用性と新規反応性の開拓}

われわれは続いて，本反応の適用性を探るととも に様々な基質に対する反応から新規反応性の探索を 行った。始めに， $\pi$ 電子不足系芳香環であり，脱 プロトン化反応が進行し易いと考えられるアジン系 化合物を基質として選択した。 ピリジン誘導体であ る 3-ブロモピリジン37,38)について検討を行った (Table 2)。基本的に親電子剤として，ベンゾチア ゾールの検討（Table 1）において最もよい結果を 与えたベンゾフェノンを用い, 溶媒としては THF あるいはトルエンを用いた。

始めに, ベンゾチアゾールとベンゾフェノンの反 応と同様な条件下反応を行ったところ（Table 2, Run 1-2), 反応はほとんど進行せず，反応温度を 室温まで昇温してもトルエン中ごくわずかに反応す るに留まった（Table 2, Run 2)。 また, $100^{\circ} \mathrm{C} へ$ 昇 温しても反応は $31 \%$ の低収率に留まり, さらに副 生成物が増加した（Table 2, Run 3). 反応温度, 溶 媒など種々検討を行ったが，反応は改善されなかっ た.

ベンゾフェノンの反応と同様な条件下では根本的 に反応の進行は困難であると考え, 反応の活性化を 目的とし，添加物による反応の促進を試みた（Table 2, Run 4-10 に代表的なものを挙げる). 添加物 として, 種々金属化合物について検討を行つたとこ ろ, $\mathrm{TiCl}_{4}, \mathrm{AlEt}_{3}, \mathrm{BF}_{3} \cdot \mathrm{Et}_{2} \mathrm{O}$ などの一般的な Lewis 酸については良好な結果が得られなかつたが，ヨウ 化亜鉛を添加した場合に反応が加速されることが明 らかとなった。 $t$-Bu-P4 塩基 : 1 当量, トルエン溶 媒中, $-78^{\circ} \mathrm{C} \rightarrow$ 室温の条件に 1 当量のヨウ化亜鉛を 添加することで，41\%の収率で目的アルコール体を 与えた (Table 2, Run 11)。ヨウ化亜鉛無添加の同 条件下では目的アルコール体の収率が 3\%（Table 2, Run 2) であることから，反応は劇的に加速され たと言える。ささらに，上記条件では原料が消失しな かったため, $t$-Bu-P4 塩基を 2 当量とし, 同様な条 件下反応を行ったところ，77\%の収率で反応が進行 した (Table 2, Run 12).

また，親電子剤としてベンズアルデヒド，ピバル アルデヒドのアルデヒドの適用も可能であった. ベ ンズアルデヒドを用いた場合には， $t$ - Bu-P4 塩基を 2 当量用いた条件で $85 \%$ の良好な収率で反応が進行 し (Table 2, Run 13), ピバルアルデヒドの場合に 
Table 2. Deprotonative 1,2-Addition of 3-Bromopyridine with $t$-Bu-P4 Base

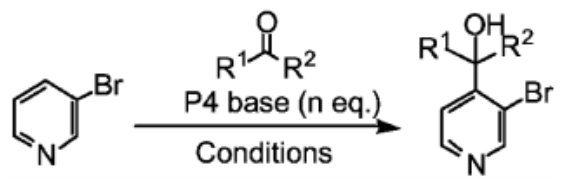

\begin{tabular}{|c|c|c|c|c|c|c|c|c|}
\hline \multirow{2}{*}{ Run } & \multirow{2}{*}{$\mathrm{R}^{1}$} & \multirow{2}{*}{$\mathrm{R}^{2}$} & \multicolumn{4}{|c|}{ Conditions } & \multirow[b]{2}{*}{ Time } & \multirow{2}{*}{ Yield (\%) } \\
\hline & & & Additive & Solvent & P4 base (n eq.) & Temp. & & \\
\hline 1 & $\mathrm{Ph}$ & $\mathrm{Ph}$ & none & THF & 1.0 & $-78^{\circ} \mathrm{C} \rightarrow$ r.t. & o.n. & 0 \\
\hline 2 & $\mathrm{Ph}$ & $\mathrm{Ph}$ & none & Toluene & 1.0 & $-78^{\circ} \mathrm{C} \rightarrow$ r.t. & o.n. & 3 \\
\hline 3 & $\mathrm{Ph}$ & $\mathrm{Ph}$ & none & Toluene & 1.0 & $-78^{\circ} \mathrm{C} \rightarrow 100^{\circ} \mathrm{C}$ & o.n. & 31 \\
\hline 4 & $\mathrm{Ph}$ & $\mathrm{Ph}$ & $\mathrm{MgBr}_{2}$ & Toluene & 1.0 & $-78^{\circ} \mathrm{C} \rightarrow$ r.t. & o.n. & 0 \\
\hline 5 & $\mathrm{Ph}$ & $\mathrm{Ph}$ & $\mathrm{Cul}$ & Toluene & 1.0 & $-78^{\circ} \mathrm{C} \rightarrow$ r.t. & o.n. & 0 \\
\hline 6 & $\mathrm{Ph}$ & $\mathrm{Ph}$ & $\mathrm{BF}_{3} \cdot \mathrm{Et}_{2} \mathrm{O}$ & Toluene & 1.0 & $-78^{\circ} \mathrm{C} \rightarrow$ r.t. & o.n. & 0 \\
\hline 7 & $\mathrm{Ph}$ & $\mathrm{Ph}$ & $\mathrm{TiCl}_{4}$ & Toluene & 1.0 & $-78^{\circ} \mathrm{C} \rightarrow$ r.t. & o.n. & 0 \\
\hline 8 & $\mathrm{Ph}$ & $\mathrm{Ph}$ & $\mathrm{AlEt}_{3}$ & Toluene & 1.0 & $-78^{\circ} \mathrm{C} \rightarrow$ r.t. & o.n. & 18 \\
\hline 9 & $\mathrm{Ph}$ & $\mathrm{Ph}$ & $\mathrm{Me}_{3} \mathrm{Si}(\mathrm{OTf})$ & Toluene & 1.0 & $-78^{\circ} \mathrm{C} \rightarrow$ r.t. & $10 \mathrm{~h}$ & 0 \\
\hline 10 & $\mathrm{Ph}$ & $\mathrm{Ph}$ & $\mathrm{Zn}(\mathrm{OTf})_{2}$ & Toluene & 1.0 & $-78^{\circ} \mathrm{C} \rightarrow$ r.t. & o.n. & 0 \\
\hline 11 & $\mathrm{Ph}$ & $\mathrm{Ph}$ & $\mathrm{Znl}_{2}$ & Toluene & 1.0 & $-78^{\circ} \mathrm{C} \rightarrow$ r.t. & o.n. & 41 \\
\hline 12 & $\mathrm{Ph}$ & $\mathrm{Ph}$ & $\mathrm{Znl}_{2}$ & Toluene & 2.0 & $-78^{\circ} \mathrm{C} \rightarrow$ r.t. & o.n. & 77 \\
\hline 13 & $\mathrm{Ph}$ & $\mathrm{H}$ & $\mathrm{Znl}_{2}$ & Toluene & 2.0 & $-78^{\circ} \mathrm{C} \rightarrow$ r.t. & o.n. & 85 \\
\hline 14 & $t-\mathrm{Bu}$ & $\mathrm{H}$ & $\mathrm{Znl}_{2}$ & Toluene & 2.0 & $-78^{\circ} \mathrm{C} \rightarrow$ r.t. & o.n. & 92 \\
\hline
\end{tabular}

も $t$-Bu-P4 塩基 : 2 当量の条件で $92 \%$ の高収率で目 的アルコール体を与えた（Table 2, Run 14）.

従来までの金属性塩基による 3-ブロモピリジン の脱プロトン一修飾反応は，ピリジン環へのアニオ ン種の付加反応, ${ }^{39,40)}$ また, ブロモ基のハロゲン一 メタル交換反応 ${ }^{41)}$ 等の副反応が進行する可能性があ るため，低温下での反応となる (Scheme 2). ${ }^{42)} t$ Bu-P4 塩基の反応は，室温での反応であるにも関わ らず円滑に反応が進行し, 温和な条件下での化学選 択的変換が実現された。

続いて, ダイアジン化合物に対して反応の適用を 行つた。まず，ピリダジンについての検討を行った (Table 3). 基本的な反応条件は，親電子剂として ベンゾフェノンを用い，親電子剤共存下での反応を 行った。 溶媒は THF あるいはトルエンを用いた。

始めに, ベンゾチアゾールの反応条件と同様な条 件，すなわち，添加物なしの条件下，反応を行った ところ (Table 3, Run 1-2), THF 中, 大変ゆっく りではあるものの反応は進行し，50\%の収率で 4 位 付加アルコール体を与えた（Table 3, Run 1). しか しながら，このような長時間の条件でも反応は完結 せず，また反応追跡の結果から反応の終息には 400 時間以上が必要であり, しかもその条件においても

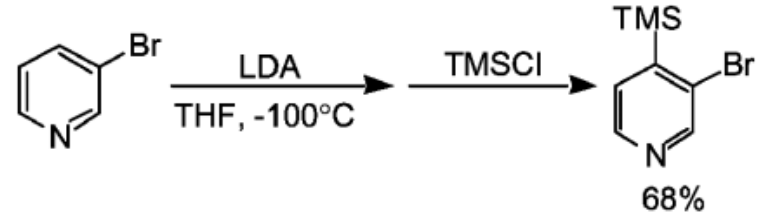

Scheme 2.

原料は完全に消失しなかった．このため，3-ブロ モピリジンにおいて良好な結果を与えたヨウ化亜鉛 添加の条件を検討した．3-ブロモピリジンの反応 と同様な条件下， $t$-Bu-P4 塩基を 1 当量用いると 57 \%の収率で目的アルコール体（4 位付加体）を与え (Table 3, Run 3), さらに 2 当量の $t$-Bu-P4 塩基を 用いることにより $91 \%$ の高収率で反応が進行した (Table 3, Run 4)。また, 親電子剤としてピバルア ルデヒドを用いた場合には同条件下，円滑に反応が 進行した（Table 3, Run 6). しかし, ベンズアルデ ヒドを用いた場合には目的アルコール体ではなく, 酸化体である 4- ベンゾイルピリダジンを与えた (Table 3, Run 5)。この酸化体の得られる理由につ いては現在のところ分かっていない.

ピリダジンは $\pi$ 電子不足系の芳香環であり求電 子性の基質であることから, 金属性塩基による脱プ 
Table 3. Deprotonative 1,2-Addition of Pyridazine with $t$-Bu-P4 Base

\begin{tabular}{|c|c|c|c|c|c|c|c|c|}
\hline \multirow{2}{*}{ Entry } & \multirow{2}{*}{$\mathrm{R}^{1}$} & \multirow{2}{*}{$\mathrm{R}^{2}$} & \multicolumn{5}{|c|}{ Conditions } & \multirow{2}{*}{ Yield (\%) } \\
\hline & & & Additive & Solvent & P4 base ( $\mathrm{n}$ eq.) & Temp. & Time & \\
\hline 1 & $\mathrm{Ph}$ & $\mathrm{Ph}$ & none & THF & 1.0 & $-78^{\circ} \mathrm{C} \rightarrow$ r.t. & $140 \mathrm{~h}$ & $50^{a)}$ \\
\hline 2 & $\mathrm{Ph}$ & $\mathrm{Ph}$ & none & Toluene & 1.0 & $-78^{\circ} \mathrm{C} \rightarrow$ r.t. & o.n. & 0 \\
\hline 3 & $\mathrm{Ph}$ & $\mathrm{Ph}$ & $\mathrm{Znl}_{2}$ & Toluene & 1.0 & $-78^{\circ} \mathrm{C} \rightarrow$ r.t. & o.n. & 57 \\
\hline 4 & $\mathrm{Ph}$ & $\mathrm{Ph}$ & $\mathrm{Znl}_{2}$ & Toluene & 1.5 & $-78^{\circ} \mathrm{C} \rightarrow$ r.t. & o.n. & 91 \\
\hline 5 & $\mathrm{Ph}$ & $\mathrm{H}$ & $\mathrm{Znl}_{2}$ & Toluene & 1.5 & $-78^{\circ} \mathrm{C} \rightarrow$ r.t. & o.n. & $0(36)^{b)}$ \\
\hline 6 & $t-\mathrm{Bu}$ & $\mathrm{H}$ & $\mathrm{Znl}_{2}$ & Toluene & 1.5 & $-78^{\circ} \mathrm{C} \rightarrow$ r.t. & o.n. & 73 \\
\hline
\end{tabular}

a) A little S.M. was obtained. $b$ ) The value in parenthesis is the yield of benzoyl pyridazine.

ロトン一修飾反応においては副反応の進行が起こり 易い．特に，無置換ピリダジンの脱プロトン一修飾 反応は，LTMP による反応が一例報告されている のみである (Scheme 3). ${ }^{43)}$ この反応も収率は中程 度以下でかつ選択性の低いものである。これに対し， $t$-Bu-P4 塩基による本反応は温和な条件下，化学選 択的，高収率の反応を実現した。

また，本反応において最も興味深いのは，反応の 位置選択性である. Scheme 3 に示すように，金属 性塩基による反応は環内窒素の $\alpha$ 位で進行する. 一般的なアジン系化合物に対する金属性塩基の反応 では，置換基 DMG（Directed Metalation Group） を持たない場合には反応は環内窒素による配向を受 け，環内窒素の $\alpha$ 位選択的に進行する. ${ }^{43,44)} t$-BuP4 塩基による反応は金属性塩基とは異なり環内窒 素より離れた位置で進行した。すなわち, $t$-Bu-P4 塩基の反応の位置選択性は Directed Metalation に 反するものであり，金属性塩基によっては達成困難 な反応の位置選択性が実現された。

ピリミジンについても反応の適用を行った。 基本 的な反応条件は，親電子剂としてベンゾフェノンを 用い，親電子剂共存下での反応を行った。溶媒は THF あるいはトルエンを用いた。 ヨウ化亜鉛無添 加の条件下（Table 4, Run 1,2）反応はほとんど進 行しなかったそそこで，3-ブロモピリジン，ピリ ダジンと同様にヨウ化亜鉛添加の条件を適用したと ころ, $t$-Bu-P4 塩基 : 1 当量の条件で 19\%の収率で 目的付加物であるアルコール体を与えた（Table 4,

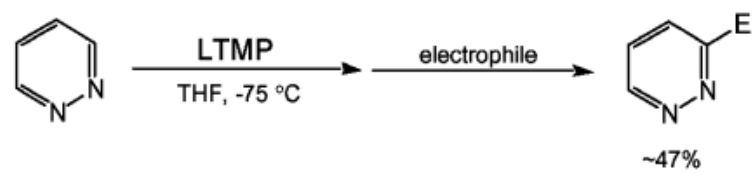

Scheme 3.

Run 3). さらに, $t$-Bu-P4 塩基を 3 当量とすること によって，収率は 48\%まで向上した（Table 4, Run 4).ただし，この条件においても原料は消失してお らず，この条件も最適条件ではない.さらに $t$ - BuP4 塩基の当量を増加させた場合, 副反応が進行す るためこの条件を妥協点とした．親電子剤にベンズ アルデヒド，ピバルアルデヒドのアルデヒドを用い た場合には状況は改善され，それぞれ 80\% （Table 4, Run 5), 65\%（Table 4, Run 6）とほぼ満足のいく 収率で反応が進行した。

この反応においても反応の位置選択性は大変興味 深いものとなつた. 反応は DMG として機能し得 る環内窒素より最も離れた位置である 5 位選択的に 進行した。すなわち，この反応も Directed Metalation に反しており, $t$-Bu-P4 塩基は金属性塩基の反 応では考えられない位置選択性を示した. ピリミジ ンの金属性塩基による反応は副反応が進行し易く困 難であるが, LTMP による反応が一例報告されて いる. ${ }^{43)}$ 環内窒素の $\alpha$ 位である 4 位での反応が進行 している (Scheme 4)。しかしながら反応収率は全 体として低い.

$t$-Bu-P4 塩基のピリダジン，ピリミジンに対する 
Table 4. Deprotonative 1,2-Addition of Pyrimidine with $t$-Bu-P4 Base

$\begin{array}{ccccccccc} & & & & & & \\ \end{array}$

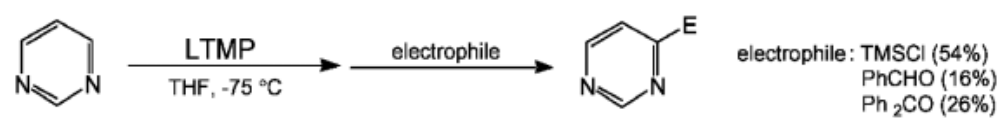

Scheme 4.

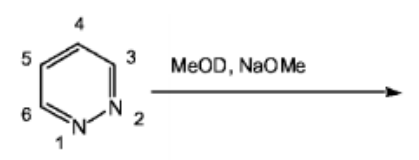<smiles></smiles>

Relative rate 3,6 position : 4,5 position $=1: 15$

Relative rate; 2 position : 4,6 position : 5 position $=1: 3.25: 46.7$

Scheme 5 .

反応において，従来までの金属性塩基による脱プロ トン一修飾反応とは異なる興味深い位置選択性が示 された。 $t$-Bu-P4 塩基による芳香族脱プロトン一修 飾反応は，従来までの金属性塩基による反応とは異 なる機構のもと進行することが推定された。これら の特異な位置選択性と同様な選択性が塩基性条件下 での $\mathrm{H}$-D 交換反応において示されている (Scheme 5). ${ }^{45)} \mathrm{H}$-D 交換反応の特異な位置選択性の起因の 1 つとして，中間体，あるいは遷移状態において生 成するアニオンあるいは電子過剩な環境と環内窒素 のロンペアとの間に生じる静電反発が考えられてお り，この静電反発を避けようと環内窒素より離れた 位置での反応が進行すると理解されている。 $t$-Bu$\mathrm{P} 4$ 塩基による反応の位置選択性も，この $\mathrm{H}$ - D 交 換反応の機構と同様な機構を取ることに由来するの かも知れない. 現在, 位置選択性の理解のため, 反
応機構の解明を検討している.

次に，ベンゼン誘導体の反応についても検討を行 つた．基質として 4-ブロモベンゾニトリルを用い 反応を試みた。

4- ブロモベンゾニトリルは，ハロゲン一メタル 交換反応が進行するブロモ基41) と親電子性でありア ニオン種の求核攻撃を受け易いシアノ基 ${ }^{46)}$ 有し,

リチウム塩基等の一般的な金属性塩基によっては脱 プロトン一修飾反応が不可能な，あるいは極めて厳 しい反応条件規制を受けた場合にのみ可能な基質で あると考えられる．様々な変換が可能であることか ら，この基質は大変有用な芳香環母核であるが，こ の基質に対する脱プロトン一修飾反応の報告はこれ まで一例もない．まず，参考とするために化学選択 性の高い芳香環脱プロトン化剤である $\mathrm{TMPZn}^{\mathrm{t}} \mathrm{Bu}_{2}$ $\mathrm{Li}^{2-4)}$ の存在下, 親電子剂としてベンズアルデヒド 
を用い，4-ブロモベンゾニトリルの脱プロトン一 修飾反応を行った（Scheme 6).

反応は収率が悪いもの 5-ブロモフェニルフタリ ドを与えた。この結果は，反応がシアノ基のオルト 位で進行し, 続くシアノ基への付加，加水分解を受 けフタリドを与えたと考えられる。すなわち，金属 塩基による反応はシアノ基のオルト位で進行するこ とが分かった，一般に，ブロモ基とシアノ基の金属 への配位能を考えた場合，シアノ基がより強い配位 能を示すことが予想され，金属塩基による脱プロト ン一修飾反応においてシアノ基のオルト位での反応 が進行することは妥当な結果であると思われる。

このような 4- ブロモベンゾニトリルに対して， $t$-Bu-P4 塩基による脱プロトン一修飾反応を試み た。 親電子剂としてベンゾフェノン共存下の条件で 反応の検討を行った（Table 5)。この反応において は，興味深いことに，用いる反応溶媒によって添加 物の必要性の有無が変化した。 トルエン中は添加物 なしの条件では全く進行しなかったが（Table 5, Run 1), ヨウ化亜鉛の添加により, $t$-Bu-P4 塩基 : 1 当量で $55 \%$ の 3 位付加アルコール体を与えた
(Table 5, Run 2)。THF 溶媒中は添加物なしの条件 でも反応が進行し， $t$-Bu-P4 塩基を 3 当量用いるこ とにより $88 \%$ の高収率で反応が進行した（Table 5, Run 3)。この場合，ヨウ化亜鉛添加の条件 (60\%：

Table 5, Run 4)よりもよい収率で反応が進行した. 親電子剂にアルデヒドを用いた場合には，ヨウ化亜 鉛添加の条件で, ベンズアルデヒド, ピバルアルデ ヒドともに良好な収率で進行した（Table 5, Run 5 -6).

金属塩基による反応は，TMPZn $\mathrm{TBu}_{2} \mathrm{Li}$ を用いて 2 位での反応が低収率ながら進行したのに対し, $t$ Bu-P4 塩基による反応は，温和な条件下，化学選択 的に高収率で進行した。

また，反応の位置選択性は親電子剂によらず 3 位 選択的に進行した。この位置選択性は $\mathrm{TMPZn}^{\mathrm{t}} \mathrm{Bu}_{2}$ $\mathrm{Li}$ による金属塩基の反応とは異なるものとなり $\left(\mathrm{TMPZn}^{\mathrm{t}} \mathrm{Bu}_{2} \mathrm{Li}\right.$ は 2 位: Scheme 2-7), この反応 においても金属性塩基とは異なる位置選択性が示さ れた。

\section{4. おわりに}

以上までの結果から，t-Bu-P4 塩基による芳香族

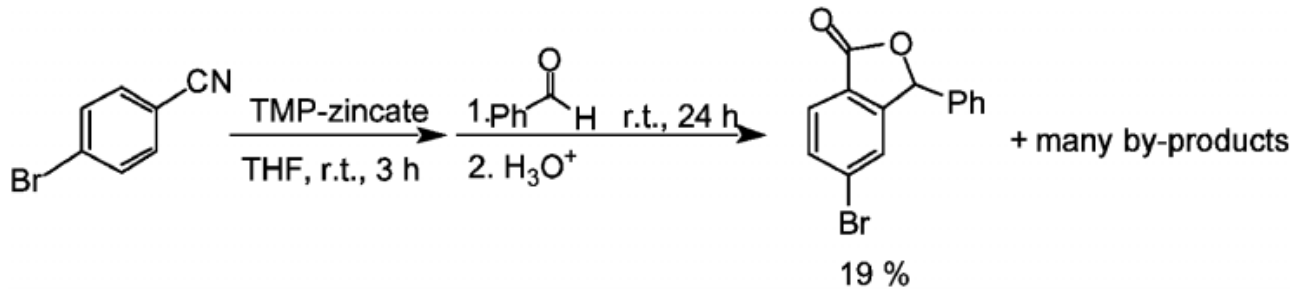

Scheme 6.

Table 5. Deprotonative 1,2-Addition of 4-Bromobenzonitrile with $t$-Bu-P4 Base

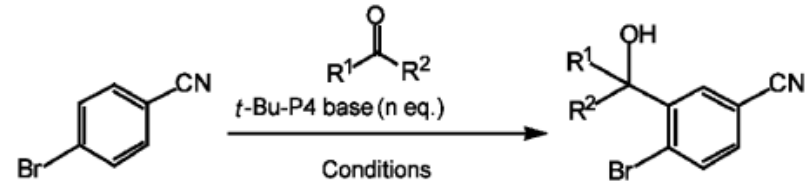

\begin{tabular}{|c|c|c|c|c|c|c|c|c|}
\hline \multirow{2}{*}{ Entry } & \multirow{2}{*}{$\mathrm{R}^{1}$} & \multirow{2}{*}{$\mathrm{R}^{2}$} & \multicolumn{5}{|c|}{ Conditions } & \multirow{2}{*}{ Yield (\%) } \\
\hline & & & Additive & Solvent & P4 base (n eq.) & Temp. & Time & \\
\hline 1 & $\mathrm{Ph}$ & $\mathrm{Ph}$ & none & Toluene & 1.0 & $-78^{\circ} \mathrm{C}$ to r.t. & o.n. & 0 \\
\hline 2 & $\mathrm{Ph}$ & $\mathrm{Ph}$ & $\mathrm{Znl}_{2}$ & Toluene & 1.0 & $-78^{\circ} \mathrm{C}$ to r.t. & o.n. & 55 \\
\hline 3 & $\mathrm{Ph}$ & $\mathrm{Ph}$ & none & THF & 3.0 & $-78^{\circ} \mathrm{C}$ to r.t. & o.n. & 88 \\
\hline 4 & $\mathrm{Ph}$ & $\mathrm{Ph}$ & $\mathrm{Znl}_{2}$ & THF & 3.0 & $-78^{\circ} \mathrm{C}$ to r.t. & o.n. & 60 \\
\hline 5 & $\mathrm{Ph}$ & $\mathrm{H}$ & $\mathrm{Znl}_{2}$ & THF & 3.0 & $-78^{\circ} \mathrm{C}$ to r.t. & o.n. & 86 \\
\hline 6 & $t-\mathrm{Bu}$ & $\mathrm{H}$ & $\mathrm{Znl}_{2}$ & THF & 3.0 & $-78^{\circ} \mathrm{C}$ to r.t. & o.n. & 87 \\
\hline
\end{tabular}


脱プロトン一修飾反応は, 高度な官能基共存性, 基 質適用性と従来までの金属性塩基とは異なる興味深 い位置選択性を実現し得る有用な反応であることが 分かった. 現在, 本反応の適用性の拡大, 特異な反 応選択性の解明を行っている.

また，フォスファゼン塩基により生成するアニオ ンはカウンターカチオンとの相互作用の弱いアニオ ンであると考えられている. ${ }^{47-49)}$ フォスファゼン 塩基により生成するアニオンの特性を活かした新規 反応の開発についても現在試みている.

謝辞本研究を遂行するにあたり, 御指導と御 鞭撻を賜りました東北大学大学院薬学研究科分子変 換化学分野 根東義則教授に厚く御礼申し上げま す. なお, 本研究の一部は日本学術振興会特別研究 員制度並びに文部科学省科学研究費補助金特別研究 員奨励費（No. 07175）の補助によるものであるこ とを付記します。

\section{REFERENCES}

1) Trost B. M., Science, 254, 1471-1477 (1991).

2) Kondo Y., Shilai M., Uchiyama M., Sakamoto T., J. Am. Chem. Soc., 121, 3539-3540 (1999).

3) Imahori T., Uchiyama M., Sakamoto T., Kondo Y., Chem. Commun., 2450-2451 (2001).

4) Uchiyama M., Miyoshi T., Kajihara Y., Sakamoto T., Otani Y., Ohwada T., Kondo Y., J. Am. Chem. Soc., 124, 8514-8515 (2002).

5) Kondo Y., Yoshida A., Sakamoto T., J. Chem. Soc., Perkin Trans. 1, 2331-2332 (1996).

6) Shilai M., Kondo Y., Sakamoto T., J. Chem. Soc., Perkin Trans. 1, 442-444 (2001).

7) Eaton P. E., Lee C.-H., Xiong Y., J. Am. Chem. Soc., 111, 8016-8018 (1989).

8) Roberts J. D., Curtin D. Y., J. Am. Chem. Soc., 68, 1658-1660 (1946).

9) Beak P., Meyers A. I., Acc. Chem. Res., 19, 356-363 (1986) .

10) Beak P., Kerrick S. T., Gallagher D. J., $J$. Am. Chem. Soc., 115, 10628-10636 (1993).

11) Anderson D. R., Faibish N. C., Beak P., J. Am. Chem. Soc., 121, 7553-7558 (1999).
12) Bauer W., Schleyer P. v. R., J. Am. Chem. Soc., 111, 7191-7198 (1989).

13) van Eikema Hommes N. J. R., Schleyer P. v. R., Angew. Chem., Int. Ed. Engl., 31, 755758 (1992).

14) van Eikema Hommes N. J. R., Schleyer P. v. R., Tetrahedron, 50, 5903-5916 (1994).

15) Saá J. M., Deyá P. M., Suñer G. A., Frontera A., J. Am. Chem. Soc., 114, 9093-9100 (1992).

16） Saá J. M., Martorell G., Frontera A., J. Org. Chem., 61, 5194-5195 (1996).

17) Stratakis M., J. Org. Chem., 62, 3024-3025 (1997).

18) Marisais F., Quéguiner G., Tetrahedron, 39, 2009-2021 (1983).

19) Marisais F., Bréant P., Ginguene A., Quéguiner G., J. Organomet. Chem., 216, 139 -147 (1981).

20) Gribble G. W., Saulnier M. G., Tetrahedron Lett., 21, 4137-4140 (1980).

21） Comins D. L., Killpack M. O., J. Org. Chem., 52, 104-109 (1987).

22) Fraser R. R., Mansour T. S., Savard S., Can. J. Chem., 63, 3505 (1985).

23) Fraser R. R., Bresse M., Mansour T. S., J. Am. Chem. Soc., 105, 7790-7791 (1983).

24) Fraser R. R., Bresse M., Mansour T. S., J. Org. Chem., 49, 3443-3444 (1984).

25) Schwesinger R., Willaredt J., Schlemper H., Keller M., Schmitt D., Fritz H., Chem. Ber., 127, 2435-2454 (1994).

26) Schwesinger R., Schlemper H., Angew. Chem., Int. Ed. Engl., 26, 1167-1169 (1987).

27) Schwesinger R., Schlemper H., Hasenfratz C., Willaredt J., Dambacher T., Breuer T., Ottaway C., Fletschinger M., Boele J., Fritz H., Putzas D., Rotter H. W., Bordwell F. G., Satish A. V., Ji G.-Z., Peters E.-M., Peters K., von Schnering H. G., Walz L., Liebigs Ann., 1055-1081 (1996).

28) Schwab P. F. H., Fleischer F., Michl J., J. Org. Chem., 67, 443-449 (2002).

29) Davis J. H., Lake C. M., Bernard M. A., Inorg. Chem., 37, 5412-5413 (1998).

30) Kraus G. A., Zhang N., Verkade J. G., Nagarajan M., Kisanga P. B., Org. Lett., 2, 2409-2410 (2000).

31) Pietzonka T., Seebach D., Chem. Ber., 124, 
1837-1843 (1991).

32) Pietzonka T., Seebach D., Angew. Chem., Int. Ed. Engl., 32, 716-717 (1993).

33) Schlaad H., Kukula H., Rudloff J., Below I., Macromolecules, 34, 4302-4304 (2001).

34) O’Donnell M. J., Delgado F., Pottorf R. S., Tetrahedron, 55, 6347-6362 (1999).

35) Solladié-Cavallo A., Crescenzi B., Synlett, 327 -330 (2000).

36) Solladié-Cavallo A., Csaky A. G., Gantz I., Suffert J., J. Org. Chem., 59, 5343-5346 (1994) .

37) Effenberger F., Daub W., Chem. Ber., 124, 2119-2125 (1991).

38) Gribble G. W., Saulnier M. G., Heterocycles, 35, 151-169 (1993).

39) Giam C. A., Knaus E. E., Pasutto F. M., J. Org. Chem., 39, 3565-3568 (1974).

40) Upton C. J., Beak P., J. Org. Chem., 40, 1094 -1098 (1975).

41) Jones R. G., Gilman H., The Halogen-Metal Interconversion Reaction with Organolithium
Compounds. Org. React. (N.Y.) , 26, 339-366 (1951).

42) Effenberger F., Daub W., Chem. Ber., 124, 2119-2125 (1991).

43) Plé N., Turck A., Couture K., Quéguiner G., J. Org. Chem., 60, 3781-3786 (1995).

44) Quéguiner G., Marsais F., Snieckus V., Epsztajin J., Adv. Heterocycl. Chem., 52, 187 -304 (1991).

45) Zoltewicz J. A., Grahe G., Smith C. L., J. Am. Chem. Soc., 91, 5501-5505 (1969).

46) Krizan T. D., Martin J. C., J. Org. Chem., 47, 2681-2682 (1982).

47) Fletschinger M., Zipperer B., Fritz H., Prinzbach H., Tetrahedron Lett., 28, 2517-2520 (1987).

48) Braun J., Hasenfratz C., Schwesinger R., Limbach H.-H., Angew. Chem. Int. Ed. Engl., 332, 2215-2217 (1994).

49) Leito I., Rodima T., Koppel I. A., Schwesinger R., Vlasov V. M., J. Org. Chem., 62, 8479 -8483 (1997). 